\title{
Gerald O`Collins, Edward Farrugia, Leksykon pojęć kościelnych i teologicznych, przełożyli ks. Jan Ożóg SJ, Barbara Żak, Wydawnictwo WAM, Kraków 2002
}

W ciągu ostatnich trzydziestu lat program badań teologicznych został bardzo wzbogacony. Nowe wyzwania jawiące się przed teologami zmuszają do stosowania jednoznacznych pojęć. Zmiany, rozwój i nowa różnorodność tematyczna stworzyły problemy językowe - dla tych zwłaszcza, którzy rozpoczynają studiowanie teologii. Studenci mogą nie rozumieć znaczenia ważnych, a nawet podstawowych terminów teologicznych.

Z pomocą w tej sytuacji przyjść może zwięzły słownik pojęć teologicznych, który nie proponuje jakiegoś systemu, lecz po prostu wyjaśnia wyrazy i zwroty kluczowe, używane w teologii współczesnej. Ukazała się taka właśnie książka w roku 2002, wydana przez Wydawnictwo Apostolstwa Modlitwy a zatytułowana: Leksykon pojęć kościelnych i teologicznych. Jest ona drugim, zmienionym i poszerzonym wydaniem Zwięzłego Słownika Teologicznego, który także w Wydawnictwie WAM ukazał się w roku 1993. Ukazu ją ca się obecnie książka wychodzi w bardzo dogodnej do korzystania formie zarówno w kwestii do formatu, jak i sposobu wydania w plastikowej oprawie.

Leksykon może okazać się bardzo pożyteczny ze względu na swoją poręczność jak też dużą ilość haseł (1134) z różnych dziedzin wiedzy teologicznej, nauki o Kościele i historii Kościoła. Hasła opracowane zostały starannie przez autorów: Geralda O`Collinsa i Edwarda Farrugia i przetłumaczone na język polski przez ks. Jana Ożoga SJ i Barbarę Żak. W sposób zwięzły podają najważniejsze wiadomości bez odnośników do bibliografii, ale z licznymi odsyłaczami do tematów pokrewnych. Włączone zostały do leksykonu niektóre terminy biblijne, katechetyczne, etyczne, historyczne, liturgiczne i filozoficzne, z którymi studenci teologii wcześniej czy później się spotkają. Chociaż leksykon adresowany jest przez autorów przede wszystkim do ludzi Zachodu (szczególnie do katolików rzymskich), wzrastające kontakty z chrze- 
ścijaństwem wschodnim zachęciły ich do dodania niektórych terminów teologii Wschodu.

Otrzymujemy zatem podręczną pomoc, z którą łatwo jest nawet podróżować i mieć ją w różnych okolicznościach, w których zachodzi potrzeba wyjaśnienia pewnych spraw bez ich głębszego studiowania. Do tego służą potężne słowniki i encyklopedie, znajdujące się jednak raczej na półkach bibliotecznych i wymagające pewnego wysiłku dla przebrnięcia przez gęsty las wiadomości. Mają one swoje niezastąpione znaczenie przy studiowaniu zagadnień naukowych, ale obok nich potrzeba takiego zwięzłego leksykonu, który przypomni nieodzowne wiadomości, pozwoli uściślić treść opracowywanych publikacji, doraźnie pomoże studiującym, będzie użyteczny dla tłumaczy, zwłaszcza dzięki indeksom.

Wielokrotnie spotykamy się w różnego rodzaju wypowiedziach publicznych i publikacjach, zwłaszcza prasowych, z rażącymi błędami w odniesieniu do wielu podstawowych spraw religijnych i kościelnych. Wszystkim tym, którzy chcieliby uczciwie informować, a może brak im dostatecznych wiadomości, ten leksykon może służyć pomocą. Nie przemęczy ich dociekanie prawdy w obszernych źródłach, a ich wypowiedzi staną się poprawne, w pełni informujące, a nie wzbudzające politowania nad bezradnością w dziedzinie religijnej. Prawda była bowiem pomijana przy studiach, a także wypaczana w swym znaczeniu i teraz to tak często odbija się brakiem wiedzy lub brakiem orientacji w zagadnieniach. Temu można jednak zaradzić, trzeba tylko wiedzieć, gdzie sięgnąć. Otóż recenzowany leksykon jest takim doskonałym źródłem informacji. Kiedy o tym wiemy, wystarczy tylko nauczyć się często do niego sięgać.

Należałoby jeszcze wskazać jedną dziedzinę wykorzystania omawianego leksykonu. Jest nią klucz do angielskojęzycznej literatury teologicznej. Oba indeksy, umieszczone na końcu książki mogą w tej sprawie oddać duże usługi. Znając termin polski, możemy znaleźć jego angielski odpowiednik, a potem szukać informacji pod poznanym hasłem, możemy także postępować w odwrotnym kierunku. Termin angielski, napotkany przy lekturze odpowiedniej literatury, który jest nam nieznany, możemy przetłumaczyć na język polski, a potem jeszcze skorzystać z właściwego hasła leksykonu, jeżeli to będzie w danym przypadku potrzebne.

Warto jeszcze nadmienić, że omawiany słownik ukazał się również w języku indonezyjskim, włoskim i ukraińskim. Przygotowywane są też tłumaczenia na inne języki obce. Nabiera więc on znaczenia powszechnego. Przez to może zostać zrealizowane pragnienie autorów wyrażone we wstę- 
pie, aby „udoskonalić jasność i ścisłość w teologii chrześcijańskiej na całym świecie".

Ta zatem, mieszcząca się w większej kieszeni, a w każdym razie nie zawadzająca w aktówce czy teczce książka, może stać się stałym towarzyszem wszystkich, którzy spotykają się, zwłaszcza zawodowo, z problematyką religijną i kościelną. Warto więc zwrócić na nią baczną uwagę i wykorzystać jej liczne walory.

ks Adam Skreczko 